\title{
Socioeconomic Determinants and Constraints to Small-scale Sheep Marketing in Gombe Metropolis, Gombe State Nigeria
}

\author{
Abdullahi Saleh*, Yau Adamu, Kubra Hamidu, Muhammad Ahmad El hafeez and Shuaib Yau \\ Department of Agricultural Economics and Extension, Federal University Kashere, Nigeria
}

Received: 帮 June 11, 2018; Published: 眥 June 20, 2018

*Corresponding author: Abdullahi Saleh, Department of Agricultural Economics and Extension, Federal University Kashere, Nigeria

\begin{abstract}
The study focused on the socio-economic and challenges faced by small-scale sheep marketers in Gombe metropolis. A multi-stage sampling technique was used to select 91 sheep marketers from four markets. Data were collected using structured questionnaire and were analysed using descriptive statistics, farm budget and multiple regression models. The results revealed that, the mean age of sheep marketers was 40.59 years, $96.70 \%$ were males, $86.81 \%$ were married, with the majority (87\%) had family size ranging from 1 - 20 persons, and had 17.68 mean years of experience. Also, the result revealed that $57.14 \%$ of the marketers combined sheep trading with other occupations to supplement their household earnings. Furthermore, the result revealed that purchasing cost for ram and ewe constituted 92.59\% ( $\$ 27,615.38 ; \$ 77.32)$ and $91.50 \%(\$ 23,793.96$; \$66.62) of the total costs respectively. Moreover, the result revealed average total return of $\$ 32,837.36$ (\$91.94) per head of animal was realized. The coefficient of multiple determination (R2) was 0.821 ; meaning that $82.10 \%$ variations in the total returns were influenced by the socio-economic characteristics included in the regression model. Also, the result revealed that, number of animals held per week was significant $(\mathrm{P}<0.01)$. Inadequate capital was critical; this was attributed to inadequate source of formal credits. Other market facilities such as clean environment and security were also lacking. However, improvement in the existing infrastructural facilities will help expand the present scale of operations. To improve efficiency, Governments and financial institutions should ensure funds in the form of loans are extended to the marketers.
\end{abstract}

Keywords: Socio economics; Determinants; Constraints; Sheep; Marketing, Gombe

\section{Introduction}

The demand for sheep and their products is destined to increase by more than $250 \%$ in Sub-Saharan Africa, especially the West Africa [1]. This will result from population growth, accelerated urbanization, incomes generation and consequently increased purchasing power of the populations. In economic terms, small ruminant rearing plays a major role in household incomes. With regards to poverty reduction [2]; reported that, about 675 million of world's rural poor, including nearly 170 million in Sub-Saharan Africa are entirely or partially dependent on small ruminant's production to feed them or obtain financial remuneration. According to [3], small ruminants are raised for various reasons such as; income generation, religious purposes, festive events, household consumption and hobby as well as security against crop failure. Moreover, small ruminants have often been found to be superior to saving money in the banks, because of the higher net annual returns [4]. Also, the skins of sheep and goats contributed significantly to the country's economy through foreign exchange [5,6]. However, the performance of market is influenced by two major factors; the structural characteristics of the market; and the competitive behavior of actors in the marketing chain. The socio-economic variables could affect production directly by influencing the volume and level of output and the marketing aspect by controlling the storage, preservation and disposal of the farm produce to the ultimate consumer [7]. The important socioeconomic determinants of the marketers include; age, gender, marital status, household size, educational attainment, years of 
marketing experience, source and volume of initial capital, annual income, membership of union, etc [8].

However, agricultural marketing is bedeviled by a lot of problems; some of which arise because of the basic characteristics and problems of Nigeria's Agriculture. Marketing constraints arise due to so many factors such as; limited knowledge and use of market information, lack of access to high-value reliable markets, socioeconomic factors, high transactional costs, inadequate property rights, lack of bargaining power, excesses of intermediaries and distance from the source of supply [9]. However, marketing constraints constitute the greatest barrier for small-scale operators when it comes to access high value markets, and these factors restrain farmers from making decisions to participate in the markets [10]. Therefore, overcoming these constraints is critical for small-scale farmers to access lucrative markets. It is worthwhile study to small ruminant to identify its production and marketing participants and as well as the constraints, to provide information that looks into the possible ways and means of increasing traders' income through accumulating capital and enhancing productivity and marketing. To this effect, the study is therefore made to achieve the following specific objectives: (a) to describe the socio-economic characteristics of sheep marketers in the study area; (b) to ascertain the effect of socio-economic characteristics on total returns of sheep marketers in the study area; (c) to identify and describe the constraints to sheep marketing in the study area.

\section{Research Methodology}

\section{The study area}

Gombe metropolis is the principal commercial centre of Gombe State, serves as the State capital as well the Headquarters of Gombe Local Government Authority. Situated on longitude $11^{\circ} 10^{\prime} \mathrm{E}$ and latitude $10^{\circ} 17^{\prime} \mathrm{N}$; and shares common boundaries with three local government areas of the state; Akko to the south-west, YemaltuDeba to the east and Kwami to the north-west covering an area of $5,200 \mathrm{~km} 2$ [11]. Moreover, Gombe town is regarded a confluence city of economic activities, by its position as the meeting point for agrobusiness people from the surrounding States of Yobe, Borno, Taraba, Adamawa and Bauchi. This advantage, made the State vibrant in all respects of the economy [11]. According to [12], Gombe metropolis had human population of 268,536 in 2006; with a projection of 363,061 people in 2017. The inhabitants of Gombe metropolis are mostly traders, civil servants, small-scale farmers and other nonagricultural service providers [11]. The study area is characterised with a warm climate, having a mean diurnal temperatures of $35^{\circ} \mathrm{C}$ to $40{ }^{\circ} \mathrm{C}$ during the hottest months of (March to May) and to about less than $30^{\circ} \mathrm{C}$ during harmattan [12]. The area has two distinct seasons based on the amount of rainfall received; the dry season (November to April) and the wet/rainy season (May to October) with an average $(850 \mathrm{~mm})$ amount of rainfall received per annum in 110 to 125 days.

\section{Sampling Procedure}

\section{Sampling and sample size}

A multi-stage sampling technique was used to select 91 sheep marketers. In stage I, Gombe metropolis was purposively selected because it is the commercial centre of the State, and also assumed to have contained majority of the target population for the study. In stage II the study area was delineated into two major sheep market districts; Gombe-north and Gombe-south and were purposively selected. In stage III, from each market district, two markets; Tikebabba and Tike-jauro-abare; Tike-pantami and Tike-nasarawo were purposively selected from Gombe-north and Gombe-south respectively. The choice was made because these markets were notably popular in sheep marketing in the State. In stage IV a total of 91 sheep marketers were selected using simple random sampling technique proportionate to the number of marketers in each market. This ensures that every member of the population has equal and independent chance of being selected [13]. However, in determining the sample size appropriate for this study, the [14] model was used, where $20 \%$ of the population was suggested. Therefore, according to this model, the appropriate sample size for this study was 91 sheep traders. A proportional allocation technique was then used to determine the number of sample from each market. For the purpose of this study, the proportion of the respondents from each market was determined using the formula below, as adopted by [15];

$$
n_{i}=\frac{(p) * n}{N}
$$

Where;

$$
\begin{aligned}
& \mathrm{n}_{\mathrm{i}}=\text { proportional ratio of each market; } \\
& \mathrm{N}=\text { estimated target population; } \\
& \mathrm{n}=\text { sample size; } \\
& \mathrm{p}=\text { population of each market. }
\end{aligned}
$$

However, according to this model, the samples were randomly and proportionally selected based on the estimated population of traders in each of the selected markets. The distribution of the proportionately estimated sample size/sampling frame (91/456) of sheep marketers in Gombe metropolis were; Tike-babba (42/209); Tike-jauro-abare (15/74); Tike-pantami (23/116); Tike-nasarawo (11/57); obtained from the Gombe State Sheep and Goat Traders Association.

\section{Method of Data Collection}

Data for this study were collected from the primary sources using structured questionnaire; this was supported with personal interview in situations where the respondents did not understand the questions. Also, an informal in situ interviews noting responses and observing the marketing process was conducted simultaneously with the formal questionnaire administration. 
This allowed for generation of qualitative information which was not captured in the questionnaire. The questionnaire modules consisted of coded and open-ended questions made to collect information on socioeconomic variables; marketing variables as well as constraints. In addition, the questionnaire also allowed respondents discuss freely the particular marketing issues of concern to them.

\section{Method of Data Analysis}

There are many analytical tools available for use in research of this kind and the choice depends on the availability of data [14]. This section describes many techniques that were used in data analysis for this study. In this study, the descriptive statistics such means and percentage; farm budget and multiple linear regression models were used.

\section{Models specification}

The mean model used for the study was therefore expressed as follows, as adopted by [16];

$$
x=\frac{\sum f x i}{\sum f}
$$

Where;

$\mathrm{x}=$ Mean of grouped data;

$\sum \mathrm{fxi}=$ Sum of products of variables and frequencies;

$\sum \mathrm{f}=$ Sum of all frequencies of variables.

To determine the total returns in sheep marketing the farm budget model was employed. Thus, costs-return analysis as described by $[17,18]$ was achieved by the following relationships;

$$
\begin{aligned}
& T C=T V C+T F C \ldots \\
& T R=P \times Q
\end{aligned}
$$

Where;

$\mathrm{TC}=$ Total marketing costs $(\mathrm{N})$;

TVC = Total variable costs (

TFC = Total fixed costs $(\mathbb{N})$;

TR = Total return $(\mathrm{N})$;

$\mathrm{P}=$ Unit price of sheep $(\mathrm{N})$;

$\mathrm{Q}=$ Number of sheep sold per week.

Moreover, the multiple liner regression model was used to estimate the cause, degree and effect relationship of some selected socio-economic variables and the total returns of sheep marketers. The model in its general form was specified as:

$$
Y=f\left(X_{1}, X_{2}, X_{3}, X_{4}, X_{5}, X_{6}, X_{7}, \ldots U_{i}\right) \ldots
$$

Where;
$\mathrm{Y}=$ Estimated total return $(\mathrm{N})$,

X1 = Age (years),

X2 = Marital status (1=married; $0=$ otherwise $)$,

X3 = Household size (number),

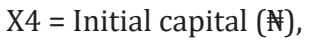

X5 = Number of animals hold per week

X6 = Marketing experience (years),

X7 = Educational level (1=primary, $0=$ otherwise $)$

$\mathrm{Ui}=$ Error term.

According to [14], the functional form of the multiple linear regression model is expressed in its explicit form as;

$Y_{i}=b_{o}+b_{1} X_{1}+b_{2} X_{2}+b_{3} X_{3}+b_{4} X_{4}+b_{5} X_{5}+b_{6} X_{6}+b_{7} X_{7}+U_{i} \ldots$

Where;

$\mathrm{bo}=$ constant

b1-b7 = regression coefficients

$\mathrm{X} 1-\mathrm{X} 7$ = independent variables

$\mathrm{Ui}=$ error term.

\section{Results and Discussion}

\section{Socio-economic characteristics of sheep marketers}

Age: in marketing studies, the age of the respondents is an important factor as it may reflect on the level of efficiency of an individual market participant. Age is a variable which describes the stages of development of an individual, either young and/or old, measured in years. It is logical to think that an individual's efficiency declines with increasing age [19]. According to [20] age is one of the factors that influence traders' decision making in resource allocation, managerial ability and responsibilities. Similarly, [21] reported that, age is a pivotal characteristic that dictates the nature and extent of traders on how to carry out marketing activities. The study revealed that $39.56 \%$ of the sheep traders were within the age bracket of 30-39 years, followed by those within the age range of 40-49 years (27.47\%), then those within the range of 20 - 29 years (13.19\%), while those above 70 years accounted for only 4.4\%; with the mean age of 40.59 years as shown in Table 1 . This implies that sheep traders in Gombe metropolis were in their active stage and can take risks in anticipation of profit. Reference [20] obtained similar findings that mean age of cattle traders in Gombe metropolis was 42 years. Reference [21] asserted that these traders were still in their economic active ages; they were assumed innovative, adaptive, physically and mentally upright that would be able to withstand any tedious activity in traditional patterns of marketing. 
Marital status: marital status simply means living single or in a matrimonial relationship which includes past and present positions such as single, married, divorce, widowed etc. [22,23]. Marital status distribution is very important as it helps to have idea of marketing participant's devotion to the marketing process and the likely outcome of this on his/her business activities. Marital status of a person determines the degree of responsibility of that person in the society and the manners in which he/she will judicious allocate the scarce resources at his or her disposal [24]. However, Table 1 shows that majority (86.81\%) of sheep marketers were married, $12.09 \%$ were single and $1.10 \%$ was divorced; meaning that marketing of sheep in the study area was dominated by married individuals. This agrees with the findings of [25], who found that $73.3 \%$ of the livestock marketers in central zone of Adamawa State were married [26]. Contended that, marriage is an important factor in the livelihood of individuals in the society as it is perceived to confer responsibility on individuals. Reference [27] also viewed married individuals have more responsibilities such as provision of foods, education, health and general well-being for the family. This might be reasons; the business is dominated by the married people unlike the case for the singles who may not likely have other people to take care of beside themselves.

Household size: this refers to the total number of individuals that live under same roof and feed from the same pot [23]. Household size is an important socio-economic variable that determines availability of family labour supply [28]. According to [20], households are those eating from one pot, and their consumption unit is equal to their production unit. It is reasonable to think that the larger the number of household members, the more the social commitments of the working adults who have the responsibility of providing the needs of the household. However, working adult depends on income from marketing activities to meet these social obligations; this can subsequently lead to more devotion to the income-generating activities they are engaged in. However, the results revealed that $42.86 \%$ had household size range of $1-10$ persons, $43.95 \%$ had $11-20$ persons, $12.09 \%$ had $21-30$ persons, and only $1.1 \%$ that had household size of $31-40$; with the mean household size of 13 persons per family (Table 1). The result agrees with the findings of [29] who reported that, the mean household size of most of marketers in northern Nigeria was 13 members per family. This implies that sheep marketers in Gombe metropolis had manageable family sizes which may add to them of extra helping hands in their ventures. Reference [30] opined that, household size determines the availability of family labour. But in contrast, [31] reported that large family size of cattle traders in Jos Plateau State had negative consequences, as the family heads bear heavy burden, which greatly undermined their investment expansion capacity.

Level of education: this improves the ability of traders to make wise marketing decisions; for most people and societies, formal education confers a wider range of opportunities and advantages for success in life compared with illiteracy [19]. It is assumed that educational attainment may lead to a better understanding of the market dynamics and thus better profit from the use of sound business principles and wise business decisions. However, Table 1 also depicts that sheep marketers with secondary education had the highest proportion (37.36\%), closely followed by those that had other forms of education, such as Islamiyah and/or adult/nonformal education (30.76\%). Moreover, those with primary education constituted $21.98 \%$, and only $9.9 \%$ that had tertiary education. It may be concluded that all sheep marketers in the study area had at least one or the other form of education. This implies that they could acquire skills and knowledge, which is important in obtaining information about marketing, thereby increasing their revenues. Reference [32] reported similar findings and concluded that, level of education attained increases the ability of the marketers to understand and evaluate information on new techniques. Also, level of formal education is assumed to have implication on the extent to which the marketers will be pro-active and receptive to new ideas, and to find it relatively easier to deal with customers in the exchange process. Although, the ability to trade farm produce is not necessarily a function of one's level of education, it however helps in the efficient performance of all the marketing functions such as; loan application, effective communication, record keeping and devising strategies on how to enhance efficient marketing activities and survive during different period by either diversifying or evolving new approach that ensure keeping him in business without necessary encountering discomfort losses.

Primary occupation: occupation is another important socio-economic variable. It indicates the status of respondent in sustaining their 1ivelihood [33]. As a component of socioeconomic status, occupation encompasses both income and educational attainment of an individual. Occupational status reflects the educational attainment required to obtain the job and income levels that vary with different jobs and within ranks of occupations [34]. The result of the study revealed that $42.86 \%$ of sheep marketers in Gombe metropolis claimed to have marketing as their primary occupation; $25.27 \%$ were crop producers; $13.19 \%$ engaged in some artisanal jobs; and $10.99 \%$ were civil servants (Table 2). This shows that most (57.14\%) of the marketers were on part time basis, such that their involvement in other different types of occupations were to augment their household incomes [35]. This corroborates with the work of [36] who found that, majority of poultry producers were civil servants in Kwara State, indicating that the activity was on part time basis; implying that they do not depend on the business as the sole means of livelihood. This is in accordance with the assertion of [37], who found that it is common for some farm households to engage in other non-farm activities to complement their earnings. Moreover, [38] found occupational distribution of gum-arabic marketers in Borno State, and revealed that majority (71\%) were farmers. This was also in agreement with the findings of [15], who reported that majority of households in sub Saharan Africa, engaged in more than one occupation. Also in accordance with [39], who reported that small-scale agro-business could be successfully combined with other vocations to ensure continuous and stable flow of incomes to the households. 
Marketing experience: is a technical skill acquired in management of marketing activities with regards to certain conditions [22]. Years of experience are a measure of the period an individual marketer was involved; and plays a very important role in every human Endeavour. It is the basis of skills acquisition and success in business [40]. According to [41], marketing experience enables traders to adequately organize and manage their businesses in expectation of better profit. However, Table 1 reveals that, most (58.24\%) of the sheep marketers in the study area had years of marketing experience range of 11-20; closely followed by $18.68 \%$ had $01-10$ years of experience. The result further revealed the mean years of marketing experience was 17.68. This could infer that, the more the years of experience in sheep marketing the less the number of traders. This might be due to the fact that, some of the traders dropped out of the business because of age or inability to take and manage risk associated with marketing of sheep in the study area. But, $[20,33,41]$, all opined that, marketers with long years of marketing experience were likely to understand the market situation thereby taking and managing risk and uncertainties in marketing activities in an attempt to generate more profit. In addition, the mean years of experience shows that the marketers were experienced enough in the business, a knowledge which would enable them understand the intricacies of the trade and thus be able to operate at a reduced marketing cost. One may conclude that sheep marketing in the study area was stable, sustainable and dependable since people stayed for long period of years. By implication, the business seems to be profitable, since nobody will spend several years in an unprofitable enterprise; this is due to the fact that experience creates behavioral confidence in the business and increases buyers - sellers' engagement and stronger relationship.

Source of initial capital: capital is one of the most important components of any investment [42]. Its availability and accessibility tend to have great influence in the marketing process. However, agricultural marketing requires considerable investment of fund in the area of bulk purchases. Source of credit/loans for financing marketing activities could have a lot of influence on the performance of marketing, since interest rates usually influence the amount of money available for investment and the profit realized from marketing [43]. The result shows that, $81.32 \%$ of the marketers claimed to have sourced their initial capital from personal savings; $10.99 \%$ from family and friends; $5.49 \%$ from rotatory savings (adashe); 1.1\% each from money lenders and cooperative societies. Furthermore, Table 1 shows that, none of the sheep marketers in Gombe metropolis that had sourced their initial capital from formal sources. Reference [44] and [15] inferred that transaction costs involved in obtaining loan and as well the delay in disbursement might be important factors that limit marketers' access to formal source of capital. Reference [45] also stated that, capital is a very strong factor that is needed to acquire or develop any enterprise; its availability could determine the extent of production and marketing capacity. Reference [46] further noted that, access to formal source of capital could have prospect in improving the productivity of traders and contributing to uplifting the livelihoods of disadvantaged rural farming communities.

Number of animals held per week: the number of animals hold and or supplied to the market depends on the market demand; differences in the quantity offered and sold varied with the trader and also varied with the market. This may be as a result of variation in marketing experience, capital, number of participants, price determinants and other factors that determined size of the business [22]. The result reveals most (54.95\%) of the sheep marketers could hold (supplied and sold) between 11 and 20 heads of sheep per week. Closely followed by those who held 1- 22 heads of sheep per week accounted for $24.18 \%$ of the marketers. The result further revealed that only $01.1 \%$ of the marketers that could supply and sell between 51 and 60 heads of sheep per week in the study area. The mean weekly number of animals supplied and sold was found to be 19 heads. According to [47], the demand for sheep as source of protein is significantly high; and also this had evidence of the appreciable profit made by the traders. However, the findings further revealed that most of the sheep marketers in the study area were operating on subsistence level. This might not be unconnected with the difficulty in acquiring the required capital, resource inputs, seasonality and as well as the speculative activities of middlemen. Studies have shown that most of the urban agricultural marketers in Nigeria operated on small-scale level; who were characterized by low productivity which leads to low income and low capital investment [35]. Number of animals supplied defines marketers' level of business operations; ceteris paribus, the higher the scale, the higher the marketing profit because of possible economies of scale. Therefore, number of animals held per week is expected to have a positive effect on the net income. But in contrast with [48] that, firm size has no effect to greater returns, because small size holdings can generate far more returns than the large scale holdings in South Africa.

Membership of union: marketing associations serve as platform for sharing experiences, identifying and solving common problems among members. Membership to groups, focusing on a product of the market chain is an important determinant of performance [49]. Presence of groups where market players can join and access the services offered increases their bargaining power for prices and a better service which consequently improves their performance in the market chain [50]. Table 1 shows the distribution of sheep marketers by membership of marketing association in the study area. The result revealed that majority (86.81\%) subscribed to the membership of sheep marketing association, whereas (13.19\%) did not subscribe to the membership of association. The implication of the result is that members of sheep marketing association might have easy access to extension services, market and credit facilities. However, [51] had similar findings and concluded that, most marketers joined Association because of the results achieved by members, mostly in terms of the association's link to markets, credit facilities and extension services. Reference [52] stated that membership of cooperative societies has 
advantages of accessibility to micro-credit, input subsidy, helps to share information and project collective demand. But, [53] obtained dissimilar findings that, only $10 \%$ were members of fire wood sellers' association in Adamawa State. The low level of involvement may be for the fact that there was a stringent government regulation that banned the indiscriminate cutting of trees; most marketers prefer to operate in isolation to avoid collision with government's Table 1: Socio-economic characteristics of sheep marketers.

\begin{tabular}{|c|c|c|c|c|}
\hline Variable & Minimum & Maximum & Range & Mean \\
\hline Age (years) & 23 & 70 & 47 & 40.59 \\
\hline Household size (number) & 1 & 32 & 31 & 12 \\
\hline Experience (years) & 3 & 43 & 40 & 17.68 \\
\hline Annual income (\#) & $1,00,000.00$ & $9,00,000.00$ & $8,00,000.00$ & $2,43,835.00$ \\
\hline $\begin{array}{l}\text { Animals held per week } \\
\text { (number) }\end{array}$ & 5 & 60 & 55 & 19 \\
\hline Variable & Frequency & & Percentage & $\mathrm{n}=91$ \\
\hline \multicolumn{5}{|l|}{ Gender } \\
\hline Male & 88 & & 96.7 & \\
\hline Female & 3 & & 3.3 & \\
\hline \multicolumn{5}{|l|}{ Marital Status } \\
\hline Married & 79 & & 86.81 & \\
\hline Divorced & 1 & & 1.1 & \\
\hline Single & 11 & & 12.09 & \\
\hline \multicolumn{5}{|l|}{ Educational Level } \\
\hline Primary school & 20 & & 21.98 & \\
\hline Secondary school & 34 & & 37.36 & \\
\hline Tertiary & 9 & & 9.09 & \\
\hline Others (Islamic etc.) & 28 & & 30.76 & \\
\hline \multicolumn{5}{|l|}{ Primary Occupation } \\
\hline Sheep marketing & 39 & & 42.86 & \\
\hline Farming & 23 & & 25.27 & \\
\hline Civil servant & 10 & & 10.99 & \\
\hline Artisan & 12 & & 13.19 & \\
\hline Other occupation & 9 & & 7.69 & \\
\hline \multicolumn{5}{|l|}{ Source of Capital } \\
\hline Personal savings & 74 & & 81.32 & \\
\hline Family and friends & 10 & & 10.99 & \\
\hline Credit institution & 0 & & 0 & \\
\hline Money lenders & 1 & & 1.1 & \\
\hline Cooperatives & 1 & & 1.1 & \\
\hline Adashe & 5 & & 5.49 & \\
\hline \multicolumn{5}{|l|}{ Membership of Union } \\
\hline Yes & 79 & & 86.81 & \\
\hline No & 12 & & 13.19 & \\
\hline
\end{tabular}

law enforcement agents. Another reason for low involvement in the association is that, most of the marketers were new entrants into the business. However, the non-members were assumed to have not enjoyed benefits accrued by the co-operative societies, through management and as well as profit maximization. pooling off resources for better expansion, efficiency and effective

Source: Field survey (2017).

\section{Costs and returns of sheep marketing per week in gombe metropolis}

Costs of sheep marketing were considered as; variable and fixed costs, while returns were obtained from the sales of live animals. The marketing cost was conceptualized as the difference between

the amount paid by the ultimate consumers and the amount received by the producer [54]. The marketing costs involved in sheep trading in the study area is the sum of transport cost, costs of casual labour, feeding costs, costs of drugs, commission fees, loading and offloading costs, phone calls, union dues, taxes, depreciation 
on durable items such as feeders, drinkers, ropes, pegs, stalls, carpentry works and other costs associated with moving live animals from the point of purchase/producer to the final consumer. However, Table 2 shows the average total costs and returns of trading average 19 heads of ram and/or ewe per trader per week. The results revealed the average total costs of marketing 19 heads of ram per week per trader were $\$ 566,686.54,(\$ 1,586.72)$ and $494,079.56(\$ 1,383.42)$ for ewe. This was because the supply costs of rams were higher than that of ewe. The results further revealed the average variable costs accounted for $99.15 \%$ and $99.02 \%$ of the average total costs of the respective animals. This agrees with [55] who conceptualised that, small-scale entrepreneurs' capital allocated to fixed inputs is low and sometimes negligible. Reference [56] and [57] further supported this idea, that the proportion of fixed cost components in small-scale agricultural marketing, mostly constituted $<1.0 \%$ of the total marketing costs in Bauchi State. In terms of returns; the average gross margin (GM) of $103,687.65$ (\$290.33) and 93,061.45 (\$260.57) were realised from the sales of 19 heads of ram and ewe respectively. This further revealed per head average net income of $\$ 5,201.86$ (\$14.57) and 4,643.06 (\$13.0) of the respective animals. The result concurred with [58], who found gross margins of $\# 6,548.00$ (\$18.33); per head of cattle in south-west Nigeria. Also [59], recorded similar results that $\$ 3,037$ ( $\$ 8.50$ ) per head of goat was realized as net income in Benue State. These corroborate the assertion of [60] that, for any small-scale agro investment to optimally achieve profitability, at least $10 \%$ of the total variable costs should be realised as net firm income. Also, in line with Kolo [39] who found the mean total return of $\$ 27,685.92$ (\$77.52) per head of animal in Dambam Local Government Area of Bauchi State and concluded that the business was profitable (Table 2).

Table 2: Costs-returns of sheep marketing in Gombe metropolis.

\begin{tabular}{|c|c|c|c|c|c|}
\hline \multicolumn{2}{|c|}{ Cost components } & \multicolumn{2}{|c|}{ Ram } & \multicolumn{2}{|c|}{ Ewe } \\
\hline (A) Variable costs (VC) & Quantity & Amount ( $\#)$ & $\%$ of TC & Amount ( $(\sharp)$ & $\%$ of TC \\
\hline Supply cost of animals & 19 heads & $5,24,692.22$ & 92.59 & $4,52,085.24$ & 91.5 \\
\hline Variable marketing costs & - & $37,151.06$ & 6.56 & $37,151.06$ & 7.61 \\
\hline Total variable costs (TVC) & - & $5,61,843.28$ & 99.15 & $4,89,236.30$ & 99.11 \\
\hline (B) Fixed costs (FC) & - & - & - & - & - \\
\hline Depreciation on durable items & - & $2,535.55$ & 0.45 & $2,535.55$ & 0.51 \\
\hline Fixed marketing costs & - & $2,307.71$ & 0.4 & $2,307.71$ & 0.38 \\
\hline Total fixed costs (TFC) & - & $4,843.26$ & 0.85 & $4,843.26$ & 0.89 \\
\hline (C) Total costs (TC) & - & $5,66,686.54$ & 100 & $4,94,079.56$ & 100 \\
\hline Return components & - & - & - & - & - \\
\hline Sales of animals (TR) & 19 heads & $6,65,521.93$ & - & $5,82,297.75$ & - \\
\hline Gross margin (GM) & 19 heads & $1,03,678.65$ & - & $93,061.45$ & - \\
\hline Net return (NR) & 19 heads & $98,835.39$ & - & $88,218.19$ & - \\
\hline
\end{tabular}

$\mathrm{NB} ; \mathrm{A} 1=\$ 0.0028$.

Source: Field survey data (2017).

\section{Effect of Socio-economic characteristics on total returns of sheep marketers}

Multiple regression analysis was used to measure and predict the degree, cause and effect relationship between the socioeconomic variables and total returns. However, Table 3 shows the results of the linear function; the choice was based on a priori expectations in terms of magnitude and direction of the coefficients, magnitude of the coefficients of multiple determinations (R2), and the overall performance of the model. The fitness of the model was confirmed by the absence of autocorrelation through the significance of the F-value. The result revealed the coefficient of multiple determinations (R2) as 0.821 . Meaning that $82.10 \%$ variations in the total returns of sheep marketers were influenced by the socioeconomic characteristics included in the model. The F-ratio was significant $(\mathrm{P}<0.01)$, meaning that the independent variables have adequately described the dependent variable included in the model. Moreover, the result further revealed that, of the nine explanatory variables included in the model, only number of animal held per week that was significant $(\mathrm{P}<0.01)$. Meaning that unit increase in the level of supply of animals in the study area would lead to unit increase in total returns realized [61]. It is generally believed that the more the experience of a market participant, the greater is the efficiency of that individual hence the higher the returns. However, the coefficient of marketing experience was positively non-significant. This was in line with the result of Table 
1; which shows the average marketing experience of 17.68 years. From this distribution, majority of the respondents were expected to have mastered the skills required for high performance in sheep marketing. This implies that length of marketing experience was not important determinant of returns in sheep marketing. This was because, those that stayed long in the business may be older, less educated and may be reluctant to adopt new trends and techniques in marketing than the young and new entrants $[62,63]$.

Table 3: Multiple linear regression analysis.

\begin{tabular}{|c|c|c|c|}
\hline Variables & Coefficients & Standard error & t-values \\
\hline (constant) & $25,584.97$ & $4,864.12$ & $5.260^{* * *}$ \\
\hline Age (X1) & 80.325 & 154.45 & 0.52 \\
\hline Marital status (X2) & $1,304.89$ & $2,199.66$ & 0.593 \\
\hline Household size (X3) & 43.598 & 176.058 & 0.248 \\
\hline Initial capital (X4) & 0.001 & 0.004 & 0.176 \\
\hline Number of animals held (X5) & 167.735 & 73.456 & $2.285^{* * *}$ \\
\hline Marketing experience (X6) & 103.227 & 183.076 & 0.564 \\
\hline Level of education (X7) & $1,290.62$ & 834.029 & 1.547 \\
\hline $\mathrm{R}$ - square & 0.821 & & \\
\hline F - value & $273.7^{* * *}$ & & \\
\hline
\end{tabular}

$* * * \mathrm{P}<0.01$ level of significance.

Source: Field survey data (2017).

Table 4: Major constraints to sheep marketing.

\begin{tabular}{|c|c|c|c|}
\hline Constraints & *Frequency & Percentage & 100 \\
\hline Non-remunerative prices & 91 & 98.9 & $1^{\text {st }}$ \\
\hline Lack of credit access & 90 & 97.8 & 96.7 \\
\hline Inadequate capital & 89 & 92.31 & $3^{\text {rd }}$ \\
\hline Poor market infrastructures & 88 & $4^{\text {th }}$ \\
\hline Scarcity of animals during festivals & 84 & $5^{\text {th }}$ & 90.11 \\
\hline Diseases and pests & 82 & 89.01 \\
\hline Transportation problems & 81 & $6^{\text {th }}$ \\
\hline
\end{tabular}

*Multiple responses.

Source: Field survey data (2017).

\section{Constraints to Sheep Marketing in Gombe Metropolis}

Table 4 reveals all (100\%) of sheep marketers in Gombe metropolis had complained seriously of non-remunerative prices on sales. This corroborates with high marketing costs especially the commission fees, transportation costs as a result of far distance from the source of supply and as well as high purchasing prices of the animals. Inadequate capital was also critical as far as sheep marketing in Gombe metropolis is concern; this was attributed to inadequate sources of credits; and had stated that if they had enough money, they would be able to increase the number of animals per supply, thereby making more profit and expand market size. Moreover, inadequate finance hinders marketers from getting the necessary resources and technologies which could assist them achieve higher marketing efficiency [64]. Reference [65] reported inadequate capital was one of major problems facing smallscale business in Benue State Nigeria. Reference [66] obtained similar findings that $93 \%$ of fish producers in Adamawa State had problem of insufficient funds which incapacitated them to provide enough inputs. However, Bakoji [67] suggested that marketers should as well join cooperatives, which could help them obtain market information; project a collective demands and also helped increase their capital through self-help contributions and help them maintain stable and uniform prices. Reference [51] further added that cooperatives serve as platforms for sharing experiences, identifying and solving common problems associated with the business. Price fluctuation in sheep markets was also a serious problem for the traders. 
For instance, while expecting the previous year's price, traders may tend to supply large volume of animals, but then the prices decreased unexpectedly. Brokers also create price instability so as to benefit themselves by misinforming traders about the prevailing market prices. This indicated that $(84.62 \%)$ of the marketers faced difficulties in forecasting their gross returns, leading to poor planning [38]. Also, too much seasonal variation in price especially during religious festivals, such that low price did not offer sufficient incentive for sufficient supply. The result agrees with [68] who asserted that frequent price variations of farm produce is a major concern to producers, marketers and consumers [69]. Added that commodity prices may reflect seasonal production patterns by being at the lowest at peak production and highest at lean period. Also, $89.01 \%$ of the marketers had complained of transport related problems, which had much dispersion. In some cases, there are insufficient vehicles to carry animals from the farms to the rural markets and then to the study area. Most of the marketers depended on commercial vehicle as their means of transportation. In some cases, there were no or the roads were seasonal. This probably increased the transport fares. Increased cost of transportation due to the increased in oil price is also another problem mentioned.

Reference [70] stated that, inadequacy of transport facilities especially in rural areas leading to high transportation cost, inefficient and inadequate storage facilities, poor marketing of agricultural produce are some of the problems facing marketing of agricultural produce in Nigeria. Reference [71] added that, high transportation costs accounted for high proportion of the total marketing costs in most parts of the country. Reference [72] reported that, armed robbers used the opportunity of having poor roads; attacked and sometimes even killed marketers. The implication here is that, transportation problems are largely responsible for the slow increase in marketing efficiency and lead to continuous subsistence level of production in many parts of the supply sources. This also made both producers and marketers to resort sales at the nearby markets thereby losing greater proportion of their supposedly income to exploitatively dubious middlemen in the area [73]. The result therefore agrees with [74] that, existence of transport bottlenecks, lack of marketing information and lack of scientific grading and sorting of animals, with the result that prices do not refer to equivalent grades in the markets, account for low marketing efficiency in the study area. Furthermore, [75] stated that transportation is necessary to satisfy the utility of place and time. He further added that, sometimes storage may be required to adjust supply levels to meet the demand at moderate prices since consumption is regular and continuous. Reference [39] admitted that any of the available modes of transportation in Dambam Local Government Bauchi State had its own inherent problem which results to emaciation, loss and death of the animals in transit. Also, the activities of unregulated livestock produce checking points and theft cases along these routes compound the marketing problems. This drastically reduces the profit of sheep marketers in the study area. The result further revealed that $98.90 \%$ of the respondents had problems of low access to formal loan to boost their marketing activities. This agrees with [76], who in their findings reported that $80 \%$ of marketers in Niger State complained of lack of credit access associated with the volume of loan, cumbersome procedures, interest rates, collaterals and several trips to the bank before loan was granted were their major problems. Reference [77]; and [78] added that small-scale agribusiness firms faced a number of barriers in obtaining credits.

Reference [79] obtained similar results that agribusiness involves huge investments requiring availability of credit facilities to enhance and encourage adoption of technologies as well as modern marketing strategies. Such credit facilities are mostly inaccessible by small-scale marketers due to stringent conditions attached to its procurement. This is because most of them operate within a vicious cycle of poverty that prevent them access to such formal loans. This implies that, without loan to facilitate the involvement and adoption of improved technologies, marketers will not be able to expand the scope of the enterprise, which in turn would not satisfy consumers' demand. The livestock sector was believed to be high employment generating sector but is constrained with so many problems, which in the long run limit expansion and thereby affect employment generation capacity [80]. Moreover, the marketers had problems of; scarcity of animals during festivals, diseases and pests, risks of buying unhealthy animals, theft/insecurity and as well as low educational level. Other market facilities such as clean environment, good sheds, veterinary services, fire services, banks, security, water supply, and good toilets etc. which contribute to efficient marketing were also lacking. Reference [81] observed that, lack of these basic amenities in and around markets add considerably to the marketing constraints, resulting in reduction in income. Security issues as the least constraint to sheep marketing in the study area was attributed to the ethnic conflicts and insurgency; in and around sources of livestock.

\section{Conclusion}

Based on the results obtained from this study, it may be concluded that the enterprise is profitable, dominated mostly by young married males who acquired one or the other form of education. The total returns recorded, implied that all the participants were able to cover the total costs incurred in sheep marketing and hence the total returns were influenced by the socio-economic characteristics of the marketers. It is however, a clear indication that the business is efficient and has the potentials of increasing the marketers' income; which can induce and attracts new entrants into the market. The study will therefore serve as a guide for further research into small ruminants' value chain, and also a base line for policy makers to intervene in designing changes and formulating a more effective market policy for the growth and development of livestock sector as a whole. 


\section{Recommendations}

Based on the findings of the study, the following recommendations were made aimed at improving sheep marketing in Gombe metropolis;

a) Meat consumption still remains the major source of proteins; as shown by positive gross margins, high and sustained investment by individuals and government in this sector is recommended, so that production and marketing of sheep will become a business away from its present subsistence state;

b) Governments and NGOs should intervene to encourage sheep marketers to engage in cooperative activities by providing the initial take-off capital needs and fostering an enabling environment for cooperative activities to thrive. This will also enable them reaps the advantage of economies of scale and help facilitate easy access to formal credit facilities;

c) Governments and other financial institutions should do more to extend funds in the form of soft loans to the marketers. This will help increase the capital base of the individual traders and also attract new entrants. Also, access to institutional credit will enable producers embark on large scale production; thereby meeting up the gaps between demand and supply especially during festive periods;

d) Governments and other stakeholders should provide favourable and functional market regulating framework that can eliminate illegal fees or taxes charged along marketing channels for small ruminants. Also, government should harmonise taxes paid by the marketers and producers so as to have a unified livestock taxing system;

e) Transportation related problems could be solved through the provision of good and accessible roads in and around the supply sources, so as to reduce the cost of conveying live animals to the markets. Also, Governments should improve policies on security measures; to help reduce the rate of insecurities like armed robbery on the highways;

f) Improvement in existing infrastructural facilities will help promote expansion of the present scale of operation. This is important once the small ruminants' producers are assured of ready market and good bargaining for their efforts in meeting the protein needs of the populace. However, Government and Marketers' unions should adequately provide the needed infrastructures in and around the sheep markets in the study area.

\section{References}

1. Delgado CL, RoséGrant MW, Meier S (2001) Livestock 2020: The Revolution Continues Communication Presentee a La Reunion Annuelle de la International Agricultural Trade Research Consortium (IATRC), Auckland, New Zealand.

2. Food and Agriculture Organisation (FAO) (2005) Livestock Sector Brief (Benin, Burkina Faso, Cote Ivories, Ghana, Guinea, Gambia, Guinea
Bissau, Liberia, Mali, Niger, Nigeria, Senegal, Sierra Leone). Livestock Information Sector Analysis and Policy branch, Animal Production and Health Division, Rome, Italy, pp. 180.

3. Azage T, Berhanu G, Dirk H (2006) Institutional Arrangements and Challenges in Market-Oriented Livestock Agriculture in Ethiopia, Paper presented at the $14^{\text {th }}$ Annual Conference of the Ethiopian Society of Animal Production (ESAP), held at Addis Ababa, Ethiopia, $5^{\text {th }}$ September, pp. 1-20.

4. Nibbering JW, Van Rheenen T, Slingerland M (2000) Assessing the Financing and Insurance Capacity of Livestock in Mixed Farming Systems. In: Slingerland M (eds.), Mixed Farming: Scope and Constraint in West African Savannah. Tropical Resource Management Paper 34: 125-139.

5. Osinowa OA (1990) Breeding Selection Reproduction and Breed Management in the Local Small Ruminant Breeds. In: Osinowa OA, Abatan AA (Eds.), The Nigerian sheep and goat Production manual, NAPRI, ABU, Zaria, Nigeria.

6. Francis PA (1990) Small Ruminant Marketing in Southwest Nigeria. Journal of Agricultural Economics 4(2): 193-208.

7. Singh BR (2004) Constraints to Sustainable Crop Production in Semiarid and North-Western Nigeria. Journal of Rural Management 7(1): 40 62.

8. Okewu J, Iheanacho AC (2015) Socio-economic Characteristics of Goat Marketers in Benue State, Nigeria. ARC Journal of Social Sciences and Humanities 1(1): 54-66.

9. Anyanwu AV (1995) Marketing as a Tool for Stimulating the Growth of Nigerian Hotel Business. Journal of Marketing 1(4): 26-32.

10. Baloyi JK (2010) An analysis of constraints facing smallholder farmers in the Agribusiness value chain: A case study of farmers in the Limpopo Province. Unpublished dissertation.

11. GSG (2015) Gombe State Government: Profile.

12.GOSEEDS (2007) Gombe State Economic Empowerment and Development Strategy: Handbook, Abuja, Dandafid Nig. Ltd, p. 11.

13. Ali A, Denga ID (1983) An Introduction to Research Methods and Statistics in Education and Social Sciences, Jos, Savannah Publishers Limited, USA.

14. Alamu JF, Olukosi JO (2010) Simplified Research Methodology: Principles and Practices: (revised edition). Great Glory Publishers, Zaria, Nigeria.

15. Saleh A, Kolo A, Idi S, Sani MH, Ochi JE (2015) Profitability and Marketing Efficiency of Small-scale Groundnut Oil Processing in Gombe Metropolis Gombe State, Nigeria. Proceedings of the $29^{\text {th }}$ Annual conference of the Farm Management Association of Nigeria (FAMAN), held at the Faculty of Agriculture, Federal University Dutse, Jigawa State, Nigeria pp. 237248.

16. Girei AA, Dauna Y, Dire B (2013) An Economic Analysis of Groundnut (Arachis hypogea) Production in Hong Local Government Area of Adamawa State, Nigeria. Journal of Agricultural and Crop Research 1(6): 84-89.

17. Olukosi JO, Erhabor PO (1980) Introduction to Farm Management Economics: Principles and Applications, Agitab Publishers Company, Zaria, Nigeria.

18. Rahman SA (2014) Fundamentals of Econometrics. Fix Impression Ltd, Abuja, Nigeria.

19. Oseni JO (2010) Effects of Deregulation Policy on Cocoa Marketing in Ondo State, Nigeria. Unpublished Ph.D. Dissertation; Federal University of Technology Akure, Nigeria, pp. 235.

20. Mohammed S, Isiaka M, Ishaku A, Zaharadden D (2013) Economic Analysis of Cattle Marketing in Gombe Metropolis, Nigeria. Asian Journal of Agricultural and Rural Development 3(12): 960-965. 
21. Usman H, Nasiru M (2005) Commodity Chain Analysis of Cattle Marketing in Nigeria; a case study of K.R.I.P Area Kano State. A report submitted to ADENI Project/NAERLS, Zaria, Nigeria.

22. Jabil YI (2009) Marketing of Selected Processed Dairy Products in Bauchi State Nigeria, Unpublished, M.Sc. Thesis; Department of Agricultural Economics and Extension, Faculty of Agriculture and Agricultural Technology, Abubakar Tafawa Balewa University Bauchi, Nigeria, pp. 113.

23. Ibrahim SS, Aliero HM (2012) An Analysis of Farmers Access to Formal Credit in the Rural Areas of Nigeria. African Journal of Agricultural Research 7(47): 6249-6253.

24. Imoh AN (2000) Women Time and Role in Livestock Production. The Nguru Mbaise Experience Animal Production in The New Millennium: challenge Option NSAP and NLPRJ. Ahmadu Bello University, Zaria, Nigeria, pp. 250-255.

25. Girei AA, Dire B, Bello BH (2014) Economics of Cattle Marketing on the Socio-economic Characteristics of Cattle Marketers in Central zone of Adamawa State, Nigeria. International Journal of Advance Agricultural Research 2(2): 1-7.

26. Oladoja MA, Adedoyin SE, Adeokun OA (2008) Training needs of fishers folk on fishing technologies. Journal of Food Agric Env Sci Technol 6(1): 31-34.

27. Taphone BG (2009) Resource Productivity and Efficiency of Groundnut Farming in Northern Part of Taraba State, Nigeria. M.Sc. Thesis; Department of Agricultural Economics and Extension. Federal University of Technology, Yola, Nigeria, p. 96.

28. Iheke OR, Obasi OI, Nwankwo JC (2008) Socio-economic Determinants and Allocate Efficiency of Arable Crop Farmer in Ikwuano Local Government Area of Abia State, Nigeria. Proceedings of the $42^{\text {nd }}$ Annual Conference of the Agricultural Society of Nigeria (ASN) pp. 809-812.

29. Pius CF, Odjurwuedernie EI (2006) Determinants of Yam Production and Economic Efficiency Among Small-holder Farmers in Southern Nigeria. Journal of Central European Agriculture 7(2): 333-338.

30. Altine G, Haruna U, Sani RM (2007) Socioeconomic Variables Influencing Adoption of SG-2000 Maize Production Technology in Bauchi L.G.A. of Bauchi State Nigeria. In: Haruna U, Jibril SA, Mancha YP, Nasiru M (eds). Consolidation of Growth and Development of Agricultural Sector. Proceedings of the $9^{\text {th }}$ Annual National Conference of the Nigerian Association of Agricultural Economics (NAAE), Abubakar Tafawa Balewa University Bauchi, Nigeria, pp. 416-420.

31. Okeke KI (2007) Economics of Cattle Marketing in Jos Plateau State Nigeria, Implications for Efficient Market Development and Sustenance in Nigeria. In: Haruna U, Jibril SA, Mancha YP, Nasiru M (eds). Consolidation of Growth and Development of Agricultural Sector. Proceedings of the $9^{\text {th }}$ Annual National Conference of the Nigerian Association of Agricultural Economics (NAAE), Abubakar Tafawa Balewa University Bauchi, Nigeria pp. 142-146.

32. Oguoma NNO (2003) Financing Small ruminants' operation along Gender Lines in Imo State Nigeria. Journal of Agriculture and Social Research 3(1): 13-28.

33. Maikasuwa MA, Jabo MS (2014) Analysis of Sheep and Goats Marketing in Sokoto Metropolis, Sokoto State, Nigeria. International Journal of Agricultural Sciences and Veterinary Medicine 2(1): 185-198.

34. Kraus MW, Keltner D (2008) Signs of Socioeconomic Status: A Thinslicing approach. Journal of Psychological Science 20(1): 99-106.

35. Salau ES, Attah AJ (2012) A Socio-Economic Analysis of Urban Agriculture in Nasarawa State, Nigeria. Journal of Production Agriculture and Technology 8(1): 17-29.

36. Nurudeen AJ (2012). Economics and Social Characteristics of Registered Poultry Egg Producers in Ilorin, Kwara State. Russian Journal of Agricultural and Socio-economic Sciences 11(11): 18-23.
37. Amaza PS (2000) Resource-use Efficiency in food Crop Production in Gombe state Nigeria. Unpublished Ph.D. Thesis; Department of Agricultural Economics, University of Ibadan, Nigeria, pp. 215.

38. Umar HY, Otitolaiye JO, Opaluwa HI (2011) Evaluation of Acacia spp (Gum Arabic) Market Structure, Conduct and Performance in Borno State, Nigeria. Journal of Agriculture and Social Science, 7(1): 17-20.

39. Kolo A (2015) Economics of Sheep Marketing in Dambam Local Government Area of Bauchi State, Nigeria. Unpublished M.Sc. Thesis; Department of Agricultural Economics and Extension, Abubakar Tafawa Balewa University Bauchi, Nigeria, pp. 108.

40. Mafimisebi TE, Okunmadewa FY (2006) Are Middlemen Really Exploitative? Empirical Evidence from the Sundried Fish Market in Southwest, Nigeria. In: Rebuilding Fisheries in an Uncertain Environment, CD-ROM of the $13^{\text {th }}$ Biennial Conference of the International Institute of Fisheries Economics and Trade.

41. Mubi AA, Michika SA, Midau A (2012) Cattle Marketing in Mubi Area of Adamawa State Nigeria. Agriculture and Biology Journal of North America 4(3): 199-204.

42. Arena CO (1998) Introduction to Agricultural Marketing Analysis for Development Economics. FUUADU Publishers, Nsukka, Nigeria.

43. Akilu Y, Catley A (2010) Livestock Export from Pastoralist Areas. International Centre Tuft University Inc. Feinstein.

44. Mafimisebi TE, Oguntade AE, Mafimisebi OE (2010) Re-Engineering Agriculture for Enhanced Performance through Financing. Journal of Economics, Finance and Administrative Sciences 15(29): 35-49.

45. Ekong EE (2003) Rural Sociology: An Introduction and Analysis of Rural Nigeria. Dove Educational Publications, Uyo, Nigeria.

46. Nasiru M, Haruna U, Garba A (2013) Economics of Livestock Marketing in Gamawa Local Government Area, Bauchi State, Nigeria: Repositioning Africa Agriculture by Enhancing Productivity Market Access Policy Dialogue and Adapting to Climate Change. $8^{\text {th }}$ AFMA Conference, Moi University press, pp. 411-424.

47. Esiobu NS, Onubuogu GC (2014) Socio-economic Analysis of Frozen Fish Marketing in Owerri Municipal Council Area, Imo State, Nigeria: An Econometric Model Approach. Scholarly Journal of Agricultural Science 4(8): 449-459.

48. Botlhoko GJ, Oladele OI (2013) Factors Affecting Farmers Participation in Agricultural Projects in Ngaka Modiri Molema District, North West Province, South Africa. Journal of Human Ecology 41(3): 201-206.

49. Emokoro CO, Ekunwe PA, Achille A (2010) Profitability and viability of catfish Farming in Kogi State, Nigeria. Journal of Agriculture and Biological Sciences 6(3): 215-219.

50. Nowakunda K, Ngambeki D, Tushemereirwe WK (2010) Increasing small scale farmers' competitive in banana (Musa spp.) Production and Marketing. Acta Hortic (ISHS) 879: 759-766.

51. Aliyu N (2015) The Roles of Women in Groundnut Value Chain in Kano State Nigeria. Unpublished M.Sc. Thesis; Department of Agricultural Economics, Faculty of Agriculture, University of Zaria, Nigeria, pp. 82.

52. Agbamu JU (2006) Essentials of Agricultural Communication in Nigeria. Malt House Press Limited, Lagos, Nigeria.

53. Ndaghu AA, Taru VB, Tizhe I, Tizhe J (2011) Analysis of Socio-economic Characteristics of Fuel Wood Marketers in Yola Metropolis, Adamawa State, Nigeria. Kamla-Raj Journal of Human Ecology 36(2): 153-157.

54. Adejobi AO (2005) Cowpea Marketing in Maiduguri, Borno State: Investigation on building a food Marketing Policy Evidence base in Nigeria. Scholarly Journal of Agricultural Science 4(8): 449-459.

55. Makka BT (2009) Economic Analysis of Tomato Production in YamaltaDeba LGA, Gombe State, Nigeria. Unpublished M.Sc. Thesis; Department of Agricultural Economics and Extension, ATBU, Bauchi, pp. 163. 
56. Haruna U, Sani MH, Danwanka HA, Adejo E (2012) Economic Analysis of Fresh Tomato Marketers in Bauchi Metropolis of Bauchi State, Nigeria. Nigerian Journal of Agriculture, Food and Environment 8(3): 1-8.

57. Nasiru MO (2010) Microcredit and Agricultural Productivity in Ogun state, Nigeria. World Journal of Agricultural Sciences 6(3): 290-296.

58. Mafimisebi TE, Bobola OM, Mafimisebi OE (2014) Fundamentals of Cattle Marketing in Southwest, Nigeria: Analyzing Market Intermediaries, Price Formation and Yield Performance. Journal of Applied Tropical Agriculture 19(1): 30-38.

59. Okewu J, Iheanacho AC (2015) Profitability of Goat Marketing in Benue State, Nigeria: A Study of Selected Local Government Areas. International Academic Journal of Educational Research 10(2): 54-74.

60. Alkali HA, Saleh A (2013) Socio-economic Profile of Camel Herders in Sokoto State, Nigeria. International Journal of Food and Agricultural Research 10(1-2): 105-108.

61. Osinowo OA (1999) Strategies towards Enhancement of small ruminant Productivity by small scale farmers in the Sahelo-Sudan Savanna areas of Nigeria, In Orskov ER, Adegbola TO, Bogoro S, Butswat ISR, et al. Proceedings of International Seminar; on promoting sustainable small-scale livestock production towards reduction of malnutrition and poverty in rural and sub-urban families in Nigeria. Held in Zaranda Hotel, Bauchi, Nigeria, pp. 42-53.

62. Abda AE, Eglal AS (2010) Economics of Fish Production and Marketing: A Case Study of Khartoum State, Sudan. Journal of Applied Science Research 6(10): 1533-1538.

63. Saleh A, Ochi, JE, Sani MH (2016) Efficiency Measurement of Modern Groundnut Oil Processing of RMP-12 and Ex-dakar Varieties in Gombe Metropolis Gombe State, Nigeria. Journal of Behavioural Economics, Finance, Entrepreneurship, Accounting and Transport 4(3): 71-80.

64. Esiobu NS, Onubuogu GC, Okoli VBN (2014) Determinants of Income from Poultry Egg Production in Imo State, Nigeria: An Econometric Model Approach. Global Advanced Research Journal of Agricultural Science 3(7): 186-199.

65. Biam CK, Koko EK (2007) Economic Appraisal of Small Scale Rice Processing Business in Benue State, Nigeria. In Nwaru JC, Mejeha RO, Okoye BC, Nwachukwu IN, Nwachukwu I, et al. Agricultural Productivity and Growth: Strategies for Meeting the Millennium Development Goals (MDGs). Proceedings of the $26^{\text {th }}$ Annual Conference of the Farm Management Association of Nigeria (FAMAN) held at the Michael Okpara University of Agriculture Umudike, Nigeria, pp. 307-309.

66. Suleiman M, Isiaka M, Ishaku A (2013) Socioeconomic Factors Influencing Profitability of Cattle Marketing in Gombe Metropolis, Nigeria. International Journal of Scientific \& Technology Research 2(12): 288-292.

67. Bakoji I (2014) Economic Analysis of Maize-cowpea Intercrop in Akko Local Government Area, Gombe State, Nigeria. Journal of the Bangladesh Association of Young Researchers 2(1): 9-20.

68. Suleiman A, Isah SI (2010) Spatial Integration of selected Markets of dried Chili pepper and Ginger in Northern Nigeria. Savannah Journal of Agriculture 1(5): 29-37.
69. Godwin BK, Grennes TJ, Craig LA (2002) Mechanical Refrigeration and the Integration of Perishable Commodity Markets. Explorations in Economic History 39(2): 154-182.

70. Awoyinka YA (2009) Cassava Marketing: Option for Sustainable Agricultural Development in Nigeria. Research Journal of Agricultural and Environmental Management 2(1): 211-223.

71. Awotide DO, Ajala SO (2007) Performance and Determinants of Maize Grain Marketing in Northern Nigeria. In Haruna U, Jibril SA, Mancha YP, Nasiru M, et al. Consolidation of Growth and Development of Agricultural Sector. Proceedings of the $9^{\text {th }}$ Annual National Conference of the Nigerian Association of Agricultural Economics (NAAE), Abubakar Tafawa Balewa University Bauchi, Nigeria, pp. 329-335.

72. Saleh A, Kolo A, Mahmud YY (2016) Socio-economic Determinants and Constraints of Modern Groundnut Oil Processing in Gombe State Nigeria. Proceedings of the $10^{\text {th }}$ International Annual conference of the African Farm Management Association (AFMA), (AFMA10), Lé Meridién Hotel, Pointé aux Piments, Mauritius, pp. 139-150.

73. Saleh A, Kolo A, Garba SA (2017) Gross Margin Analysis of Modern Groundnut oil Extraction in Gombe Metropolis Gombe State, Nigeria. World Journal of Agricultural Research 5(2): 58-63.

74. Olukosi JO, Isitor SU (1990) Introduction to Agricultural Marketing and Prices: Principles and Applications. Living Books Series/G.U. Publications, Abuja, Nigeria.

75. Abbot JC (1975) Marketing Problems and Improvement Programme: Food and Agriculture Organisation, Marketing Guide No. I, Rome, Italy.

76. Mohammed U, Olaleye RS (2015) Assessment of Demographic Characteristics of Women Involvement on the Improved Methods of Groundnut Processing in Three (3) Local Government Areas of Niger State, Nigeria. American Journal of Experimental Agriculture 6(5): 326332 .

77. Daneji MI, Malumfashi AI, Muhammed SG (2006) Profitability Analysis of Groundnut Production in Bauchi L.G.A. of Bauchi State, Nigeria. Savannah Journal of Agriculture 1(2): 165-170.

78. Saito KA (2009) Agricultural Extension for Women Farmers in Nigeria. World Bank Discussion Paper, Washington DC, USA.

79. Mustapha SB, Undiandeye UC, Sanusi AM, Bakari S (2012) Analysis of Adoption of Improved Rice Production Technologies in Jere local government area of Borno state, Nigeria. International Journal of Development and Sustainability 1(3): 1112-1120.

80. Govindaraj G, Vimal K (2011) Economics of Non-oil Value Chains in Peanut: A Case of Peanut-Candy and Salted-Peanut Small-scale units in India. Journal of Agricultural Sciences 56(1): 37-54.

81. United Nations Development Programme (UNDP) (1997) The Impact of New Crop Technology on the Agricultural Division of Labour in a West African Setting. Journal on Economic Development and Cultural Change 37(3): 513-534. 


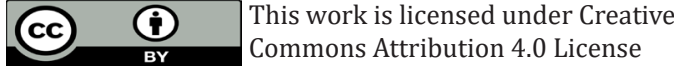

To Submit Your Article Click Here:

Submit Article

DOI: $10.32474 /$ CIACR.2018.03.000157

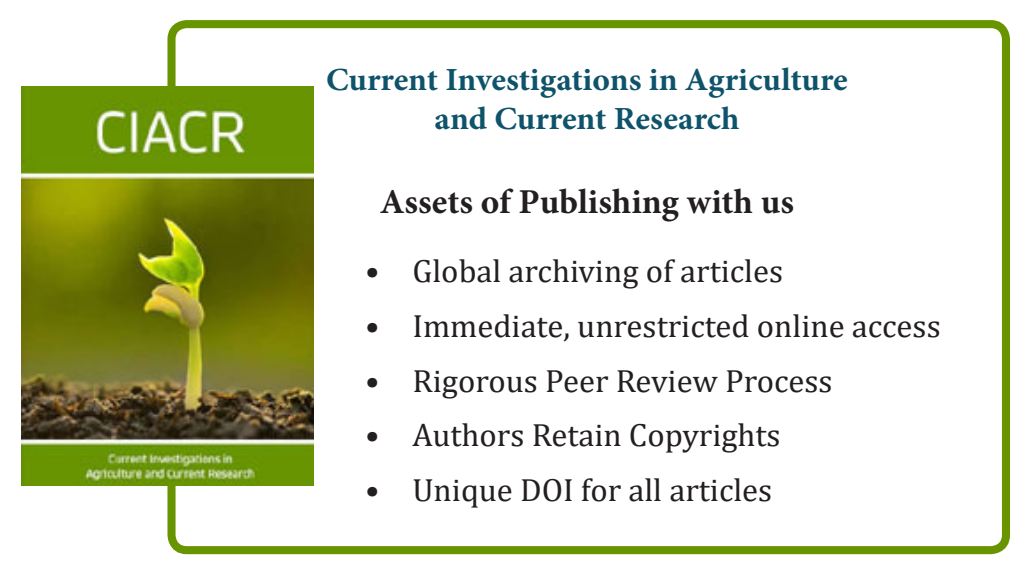

